\title{
Kesalahan Penggunaan Obat Ibu dan Balita Peserta Posyandu di Kecamatan Sukolilo, Surabaya
}

\author{
Anita Purnamayanti, Agnes Nuniek Winantari, Nani Parfati, Ida Diana, Nurul Latifah, dan \\ Tri Setyowati
}

Fakultas Farmasi, Universitas Surabaya

Korespondensi: Anita Purnamayanti

Email: anita_p_rahman@yahoo.com

\begin{abstract}
ABSTRAK: Kesalahan penggunaan obat (Medication Administration Error, MAE) pada ibu hamil dan anak merupakan jenis kesalahan penggunaan obat yang lazim dijumpai di komunitas. Orang tua berperan penting dalam pemberian obat bagi anak, terutama pada balita. Pos Pelayanan Terpadu (Posyandu) di Indonesia merupakan Upaya Kesehatan Berbasis Masyarakat (UKBM) yang secara terpadu meningkatkan kesehatan ibu dan balita, yang bertujuan untuk mengatasi ketimpangan akses terhadap fasilitas pelayanan kesehatan maupun terhadap tenaga kesehatan. Penelitian observasional yang dilaksanakan di Posyandu di Kecamatan Sukolilo secara prospektif ini dirancang untuk mengkaji kesalahan penggunaan obat yang mungkin terjadi di masyarakat. Sukolilo merupakan Kecamatan yang unik, karena keragaman di bidang sosioekonomi, maupun kemampuan masyarakatnya untuk mengakses tenaga kesehatan dan fasilitas pelayanan kesehatan. Penelitian ini berlangsung selama bulan Januari sampai Mei 2013, dengan metode wawancara penggunaan obat oleh ibu hamil dan orang tua untuk anak balitanya. Hasil penelitian dikelompokkan berdasarkan algoritma dan diagram National Coordinating Council for Medication Error Reporting and Prevention. Terdapat MAE pada penggunaan obat ibu hamil dan balita. Jenis kesalahan penggunaan obat yang tersering adalah "Terjadi kesalahan, tidak membahayakan" kategori "B", “C”, dan "D”. Selain itu, "Terjadi kesalahan, Membahayakan" kategori "E" dan "F” juga terdapat, namun tidak ada "Terjadi Kesalahan, Mematikan". Jenis MAE tersering adalah "obat tidak diberikan", dan "dosis dan frekuensi obat tidak tepat", terutama pada penggunaan antibiotik. Kesalahan ini dapat dicegah melalui pemberian edukasi kepada orang tua untuk meningkatkan pemahaman mengenai cara penggunaan obat.
\end{abstract}

Kata kunci: Medication Administration Error; Posyandu; ibu hamil; balita

\begin{abstract}
Medication Administration Error (MAE) in pediatric and maternal medication are the administration errors commonly occured in the community. Parents play an important role in the pediatric's medicine administration, especially in under five years old children. In Indonesia, Posyandu is a public-based integrated healthcare facility for promoting maternal and under five years old child health, in order to overcome the disparities in accessing a healthcare facility and healthcare professionals. This observational study was conducted prospectively in Posyandu at Sukolilo District in order to review the MAEs which might be occured in the community. Sukolilo is a unique Distric in Surabaya which is vary in sosio-economic aspects, as well as the access to healthcare professionals and healthcare facility. The study period was last from January-May 2013, interviewing medication administration in pregnant mother and mother of under five years old children. The results of the study were classified using National Coordinating Council for Medication Error Reporting and Prevention algorithm and diagram. There were MAEs in pregnant mother and mother of under five years old children. The most frequent MAEs were in "Error, No Harm" Cathegory of " $B$ ", " $C$ ", and " $D$ ". There were "Error, Harm" Cathegory of " $E$ " and " $F$ " as well; but there was no "Error, Death" Cathegory of NCC-MERP. The most frequent MAE's type were "missed dose", "incorrect dosing and frequency", especially for antibiotics administration. This error could be prevented by giving education for the parents to improve their knowledge on medication administration.
\end{abstract}

Keywords: Medication Administration Error; Posyandu; pregnant mother; under five years old children 


\section{Pendahuluan}

Populasi anak Inodnesia berusia kurang dari lima tahun (balita, bawah lima tahun) pada tahun 2012 adalah sebanyak 24.622.000 [1]. Dari populasi tersebut, tingkat kematian balita pada periode yang sama, sebesar 152.000 balita $(0,61 \%)$ atau 31 balita per 1000 kelahiran hidup. Sedangkan angka kematian ibu hamil di Indonesia adalah 190 kematian tiap 100.000 kelahiran hidup. Hal ini masih jauh dari target Millenium Development Goals (MDGs) yang harus dicapai pada tahun 2015, yaitu angka kematian balita sebanyak 28 orang per 1000 kelahiran hidup, dan 110 kematian ibu hamil per 100.000 kelahiran hidup [1-3].

Penyebab kematian ibu hamil tertinggi di Indonesia adalah karena perdarahan, yang dapat dicegah dengan pemberian Tablet Tambah Darah (TTD). Sedangkan penyebab kematian balita tertinggi adalah kelahiran prematur, penyulit kelahiran, pneumonia dan penyakit yang dapat dicegah dengan imunisasi. Penyebab kematian balita yang relatif cukup tinggi terjadi adalah karena diare ( $6 \%$ dari total kematian balita pada tahun 2012). Sedangkan balita penderita diare yang mendapatkan oral rehydration therapy (oralit) hanya sekitar $60 \%$ sejak tahun 2000 sampai dengan 2012 [1-3].

Oleh karena itu, sangatlah penting untuk menjamin kesehatan ibu hamil dan balita. Kesehatan ibu hamil dan balita berkaitan dengan perilaku pencegahan penyakit, pemeliharaan dan peningkatan kesehatan, serta pemberian obat. Secara khusus, penggunaan obat balita sangat bergantung kepada perilaku pemberian obat oleh orang tuanya [4,5]. Penelitian ini dilakukan untuk mengkaji perilaku penggunaan obat pada balita dan ibu hamil peserta Posyandu, karena umumnya kelompok masyarakat inilah yang memiliki keterbatasan akses ke sarana pelayanan kesehatan, berasal dari tingkat pendidikan rendah dan tingkat ekonomi menengah ke bawah. Sedangkan perilaku penggunaan obat dipengaruhi banyak faktor, termasuk tingkat pendidikan, budaya, dan sosial ekonomi $[4,5]$.
Obat yang diberikan kepada balita maupun ibu hamil dapat berupa obat untuk pencegahan dan pengobatan penyakit, serta pemeliharaan dan peningkatan kesehatan. Perilaku penggunaan obat yang dimaksudkan dalam penelitian ini adalah penggunaan obat oleh orang tua balita dan ibu hamil secara mandiri maupun obat yang berasal dari resep dokter. Imunisasi dan obat yang penggunaannya memerlukan bantuan tenaga kesehatan tidak dimasukkan sebagai perilaku penggunaan obat oleh ibu hamil dan orang tua balita.

\section{Metode}

Penelitian ini merupakan jenis penelitian non eksperimental, yang dilaksanakan secara potong lintang (cross sectional) [6-10]. Posyandu dan Pos PAUD Terpadu (PPT) di Kecamatan Sukolilo dibagi menjadi tiga, sesuai wilayah kerja Puskesmas yang ada di Kecamatan tersebut, yaitu wilayah kerja Puskesmas Keputih, Menur, dan Klampis. Kunjungan ke Posyandu dan PPT pada masingmasing wilayah kerja Puskesmas dipilih secara purposive sampling, disesuaikan dengan jadwal kunjungan bidan Puskesmas ke Posyandu pada tiap bulan. Kunjungan ke Posyandu ini menyesuaikan dengan kebijakan pemerintah yang telah ditetapkan [11-14]. Seluruh ibu hamil dan orang tua balita peserta Posyandu dan PPT yang dikunjungi tersebut dilibatkan dalam penelitian (selanjutnya disebut responden), dengan lebih dahulu dijelaskan mengenai penelitian ini, dan persetujuan responden dibuktikan dengan menandatangani formulir informed consent.

Selanjutnya dilakukan wawancara mengenai penggunaan obat pada ibu hamil dan balita, dan hasil wawancara dicatat oleh peneliti ke dalam lembar pengumpul data.Wawancara terdiri dari dua bagian, yaitu bagian pertama mengenai demografi responden dan balita, serta bagian kedua mengenai penggunaan obat dan masalah yang mungkin terjadi. Pengolahan data masalah penggunaan obat (medication administration error, 
MAE) dikelompokkan menurut algoritma dan diagram sistem klasifikasi Kesalahan Penggunaan Obat dari National Coordinating Council for
Medication Error Reporting and Prevention (NCCMERP) tahun $2001[15,16]$ seperti tercantum pada Gambar 1 dan Gambar 2.

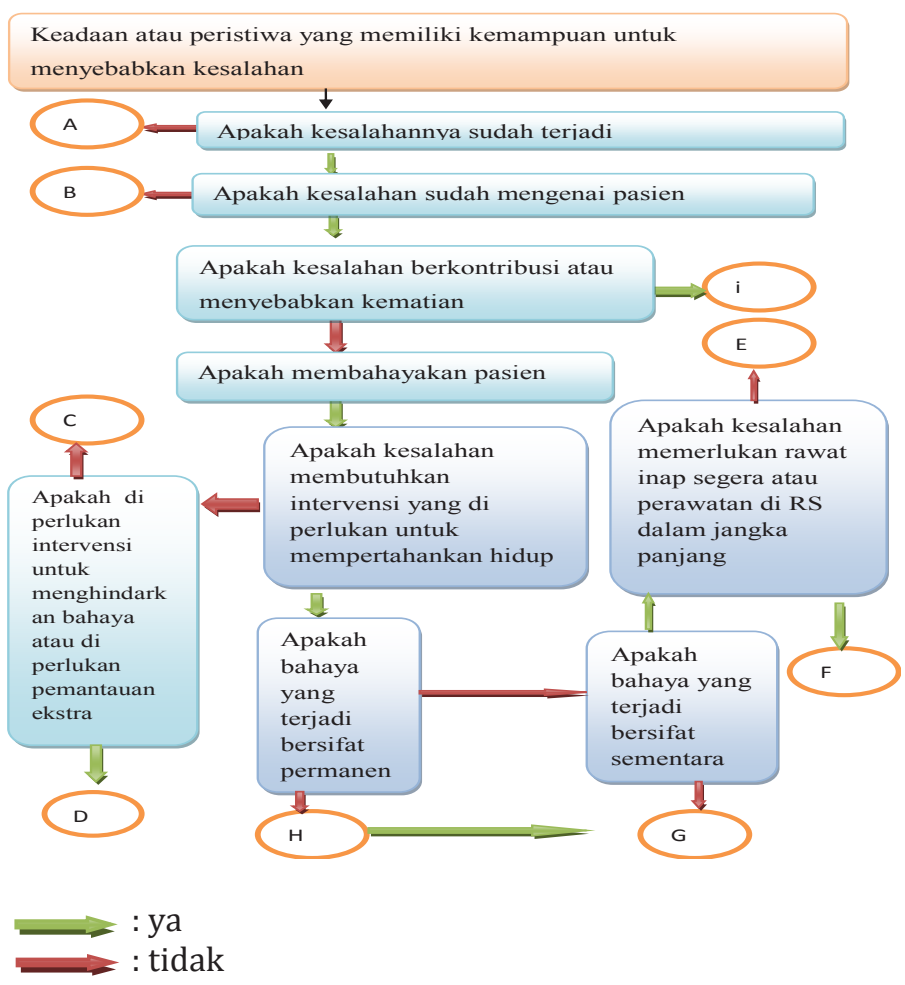

Gambar 1. Algoritma klasifikasi kesalahan penggunaan obat menurut NCC-MERP (2001)

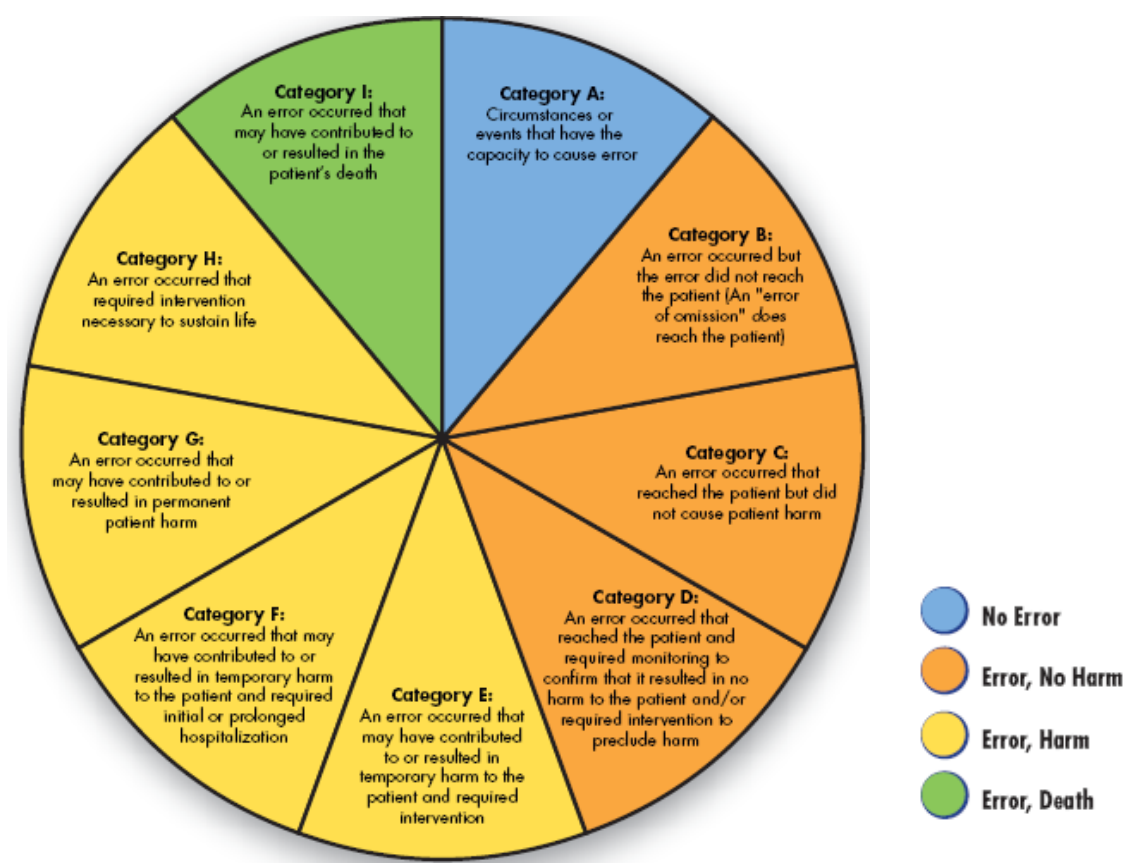

Gambar 2. Diagram klasifikasi kesalahan penggunaan pengobatan menurut NCC-MERP (2001) 


\section{Hasil dan pembahasan}

Jumlah reponden ibu hamil yang bersedia dilibatkan dalam penelitian ini adalah 33 orang dari 52 ibu hamil (63,5\%), dan responden orang tua balita sebanyak 139 orang dari 151 orang tua balita $(92,1 \%)$. Ibu hamil yang tidak bersedia dilibatkan sebanyak 2 orang, dan 17 orang ibu melahirkan pada saat penelitian dan 6 orang tidak dapat ditemui. Sedangkan orang tua balita yang menolak dilibatkan sebanyak 8 orang, dan 4 orang tidak dilibatkan karena bukan orang tua balita atau balita belum pernah mendapatkan obat. Terdapat responden ibu hamil yang sekaligus menjadi responden orang tua balita. Data demografi responden dapat dilihat pada Tabel 1 dan Gambar 3.

Jenis obat yang terbanyak digunakan ibu hamil dan balita tercantum pada Tabel 2 dan Tabel 3. Analisis obat didasarkan pada pustaka
$[17,18]$. Terdapat masalah penggunaan obat pada ibu hamil dan balita yang diberikan oleh orang tua balita (Gambar 4, Gambar 5, Tabel 4, dan Tabel 5). Masalah penggunaan obat (medication administration error, MAE) menurut klasifikasi dari NCC-MERP yang didapatkan pada penelitian ini adalah kategori "B" (terjadi kesalahan, tetapi kesalahan tersebut tidak mencapai pasien), hal ini disebabkan kesalahan segera disadari dan diperbaiki sebelum obat diberikan kepada ibu hamil atau balita. Jenis kesalahan ini tersering akibat kesalahan dalam penyimpanan obat, sehingga menyebabkan obat meleleh atau berubah warna dan tidak jadi diberikan kepada pasien. Kesalahan penggunaan obat kategori "C" (kesalahan telah terjadi dan mencapai pasien, namun tidak membahayakan pasien), yaitu tersering berupa "lupa/terlewat/tidak memberikan obat" dari golongan multivitamin pada balita. Suplemen vitamin diperlukan jika tidak dapat dipenuhi

Tabel 1. Karakteristik responden berdasarkan tingkat pendidikan

\begin{tabular}{lllll}
\hline \multirow{2}{*}{ Tingkat pendidikan } & \multicolumn{2}{l}{ Responden ibu hamil } & \multicolumn{2}{l}{ Responden orang tua balita } \\
\cline { 2 - 5 } & Jumlah & Persentase (\%) & Jumlah & Persentase (\%) \\
\hline Tidak sekolah & - & 0 & 4 & 2,88 \\
SD & 5 & 15,15 & 13 & 9,35 \\
SMP & 10 & 30,31 & 28 & 20,14 \\
SMA & 14 & 42,42 & 71 & 51,08 \\
Perguruan tinggi & 4 & 12,12 & 23 & 16,55 \\
\hline Total & 33 & 100 & 139 & 100 \\
\hline
\end{tabular}

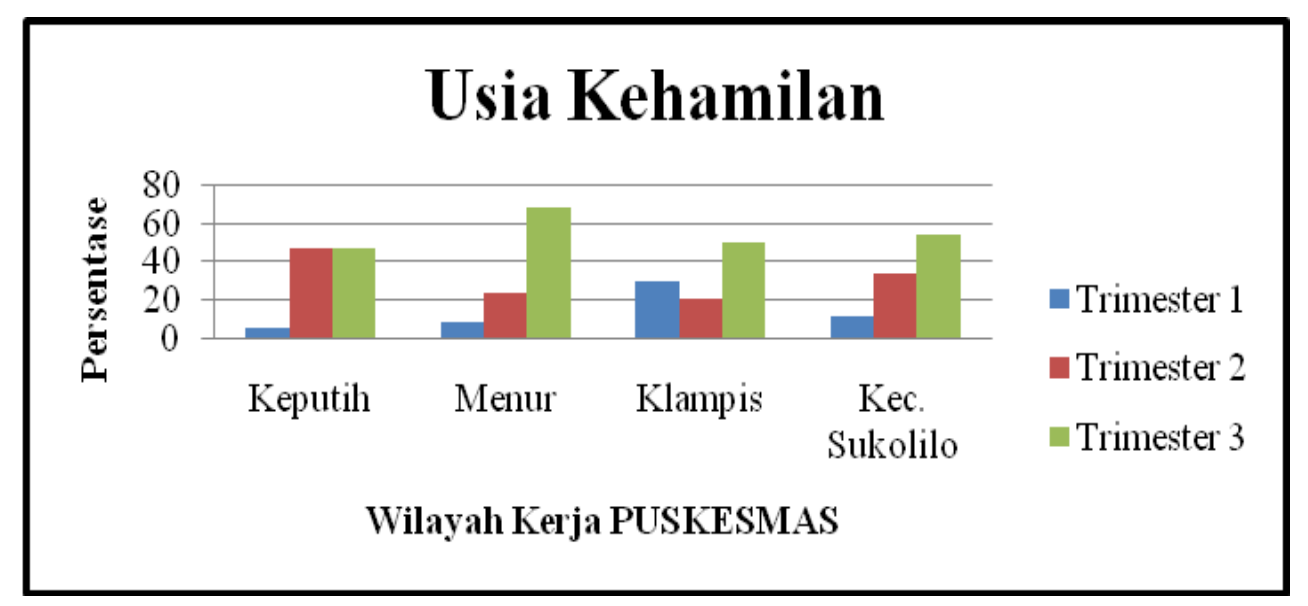

Gambar 3. Distribusi usia kehamilan responden ibu hamil 
Tabel 2. Golongan dan jenis obat yang digunakan oleh responden ibu hamil

\begin{tabular}{|c|c|c|}
\hline Golongan dan jenis obat & \multirow[t]{2}{*}{ Jumlah jenis obat } & \multirow[t]{2}{*}{ Persentase (\%) } \\
\hline A. Vitamin dan mineral & & \\
\hline Tunggal & & \\
\hline 1. Asam folat & 1 & 2,27 \\
\hline 2. $\mathrm{Fe}$ & 30 & 68,18 \\
\hline 3. Kalsium & 28 & 63,64 \\
\hline 4. Vitamin $B_{1}$ & 2 & 4,54 \\
\hline 5. Vitamin $\mathrm{B}_{2}$ & 1 & 2,27 \\
\hline 6. Vitamin $\mathrm{B}_{6}$ & 17 & 38,64 \\
\hline 7. Vitamin $\mathrm{B}_{12}$ & 6 & 13,64 \\
\hline $\begin{array}{l}\text { 8. DHA } \\
\text { Kombinasi }\end{array}$ & 4 & 9,09 \\
\hline$\frac{\text { Kombinasi }}{\text { 1. Multivitamin }}$ & & \\
\hline $\begin{array}{l}\text { 1. Multivitamin } \\
\text { 2. Multivitamin + herbal }\end{array}$ & 14 & 31,82 \\
\hline & 1 & 2,27 \\
\hline B. Analgesik, antipiretik, anti radang & & \\
\hline Tunggal & & \\
\hline 1. Ibuprofen & 1 & 2,27 \\
\hline 2. Parasetamol & 1 & 2,27 \\
\hline Kombinasi (+ dekongestan) & & \\
\hline $\begin{array}{l}\text { 1. Parasetamol, fenilpropanolamin } \mathrm{HCl} \text {, klorfeniramin } \\
\text { maleat }\end{array}$ & 1 & 2,27 \\
\hline $\begin{array}{l}\text { 2. Parasetamol, fenilpropanolamin } \mathrm{HCl} \text {, deksklorfeniramin } \\
\text { maleat, dekstrometorfan } \mathrm{HBr} \text {, gliseril guaiakolat }\end{array}$ & 1 & 2,27 \\
\hline C. Obat gastrointestinal & & \\
\hline 1. Metoklopramid & 1 & 2,27 \\
\hline 2. Antasida (hidrotalsit, $\mathrm{MgOH}$, simetikon) & 2 & 4,54 \\
\hline 3. Anti diare (attapulgit koloid aktif, pektin) & 1 & 2,27 \\
\hline 4. Pyrathiazine theoclat & 1 & 2,27 \\
\hline D. Obat antihipertensi: dopamet & 1 & 2,27 \\
\hline E. Obat antibiotik: amoxicillin & 1 & 2,27 \\
\hline F. Obat vaginal (suppositoria) & 1 & 2,27 \\
\hline G. Jamu (kunir/kunyit) & 8 & 18,18 \\
\hline
\end{tabular}

dari asupan makanan. Tetapi apabila gizi pada makanan balita telah mencukupi kebutuhan harian, maka kesalahan jenis ini tidak menimbulkan bahaya bagi balita [19-21]. Pada penelitian ini, diklasifikasikan sebagai kategori "C" setelah dicek ulang dengan data sekunder dari buku Kesehatan Ibu Anak (KIA) milik peserta Posyandu tersebut yang berisi catatan bidan mengenai perkembangan kesehatan balita dan dari penjelasan orang tua balita.

Kesalahan penggunaan obat kategori "D" (kesalahan telah terjadi dan mencapai pasien serta memerlukan pemantauan untuk memastikan tidak ada bahaya bagi pasien dan/ atau memerlukan intervensi untuk mencegah bahaya), yang terbanyak berkaitan dengan "lupa / terlewat / tidak memberikan obat" yang seharusnya diperlukan, seperti Tablet Tambah Darah (TTD) untuk ibu hamil dan antibiotik. Kesalahan penggunaan antibiotik balita yang diperoleh dari resep dokter, yaitu diberikan oleh orang tua balita hanya jika masih ada gejala penyakit, namun segera dihentikan saat balita telah "terlihat sehat" menurut ukuran dari orang tua balita. Kesalahan jenis ini relatif sedikit, karena hanya sedikit orang tua balita yang memastikan bahwa obat anaknya adalah antibiotik, berdasarkan keterangan dari dokter atau apoteker. Namun lebih banyak kesalahan terjadi karena pasien tidak mengetahui jenis obatnya. Penelitian lain juga mendapatkan hasil bahwa 
Tabel 3. Golongan dan jenis obat yang digunakan oleh balita berdasarkan penjelasan orang tua balita

\begin{tabular}{|c|c|c|}
\hline Jenis obat & Frekuensi & Persentase (\%) \\
\hline \multicolumn{3}{|l|}{ Obat dengan resep dokter } \\
\hline 1. Batuk & 85 & 11 \\
\hline 2. Pilek & 84 & 11 \\
\hline 3. Panas & 80 & 11 \\
\hline 4. Diare & 13 & 2 \\
\hline 5. Alergi (gatal) & 8 & 1 \\
\hline 6. Muntaber & 3 & 1 \\
\hline 7. Flu & 3 & 1 \\
\hline 8. Radang tenggorokan & 3 & 1 \\
\hline 9. Muntah & 2 & 1 \\
\hline 10. Gejala tifus & 2 & 1 \\
\hline 11. Kuku putus (dicabut) & 1 & 1 \\
\hline 12. Infeksi saluran kencing & 1 & 1 \\
\hline 13. Demam berdarah & 1 & 1 \\
\hline 14. Maag & 1 & 1 \\
\hline 15. Sakit kulit (bintik-bintik) & 1 & 1 \\
\hline 16. Sembelit & 1 & 1 \\
\hline 17. Kembung & 1 & 1 \\
\hline 18. Mual & 1 & 1 \\
\hline 19. Pencegah radang otak & 1 & 1 \\
\hline Total obat dengan resep dokter & 292 & 50 \\
\hline \multicolumn{3}{|l|}{ Obat non resep } \\
\hline 1. Panas & 58 & 7 \\
\hline 2. Pilek & 44 & 6 \\
\hline 3. Flu & 3 & 1 \\
\hline 4. Alergi & 3 & 1 \\
\hline 5. Sariawan & 2 & 1 \\
\hline 6. Sakit tenggorokan & 1 & 1 \\
\hline 7. Muntah darah & 1 & 1 \\
\hline 8. Diare & 1 & 1 \\
\hline 9. Penambah darah & 1 & 1 \\
\hline Total obat non resep & 172 & 27 \\
\hline Vitamin & 102 & 14 \\
\hline Imunisasi & 4 & 1 \\
\hline Jamu & 54 & 7 \\
\hline Total obat & 624 & 99 \\
\hline "Non obat": plester, kompres, dll. & 8 & 1 \\
\hline Total obat + non obat & 632 & 100 \\
\hline
\end{tabular}

lebih banyak orang tua balita atau ibu hamil tidak mengetahui jenis obat yang diresepkan oleh dokter [22-31]. Obat untuk ibu hamil yang wajib dikonsumsi untuk kesehatan ibu dan janin, antara lain kalsium, vitamin D, dan Tablet Tambah Darah (TTD). Ketiga jenis obat tersebut dapat mencegah penyebab kematian ibu hamil, yaitu perdarahan dan hipertensi dalam kehamilan [32].
Jika kesalahan penggunaan obat balita dibandingkan, maka jenis kesalahan kategori "C" (kesalahan telah terjadi dan mencapai pasien, namun tidak membahayakan pasien) paling banyak terjadi, disebabkan oleh obat yang diberikan baik dari resep dokter maupun non resep merupakan obat yang bersifat simptomastis, dan dapat dihentikan pemakaiannya jika gejala telah mereda. Se- 


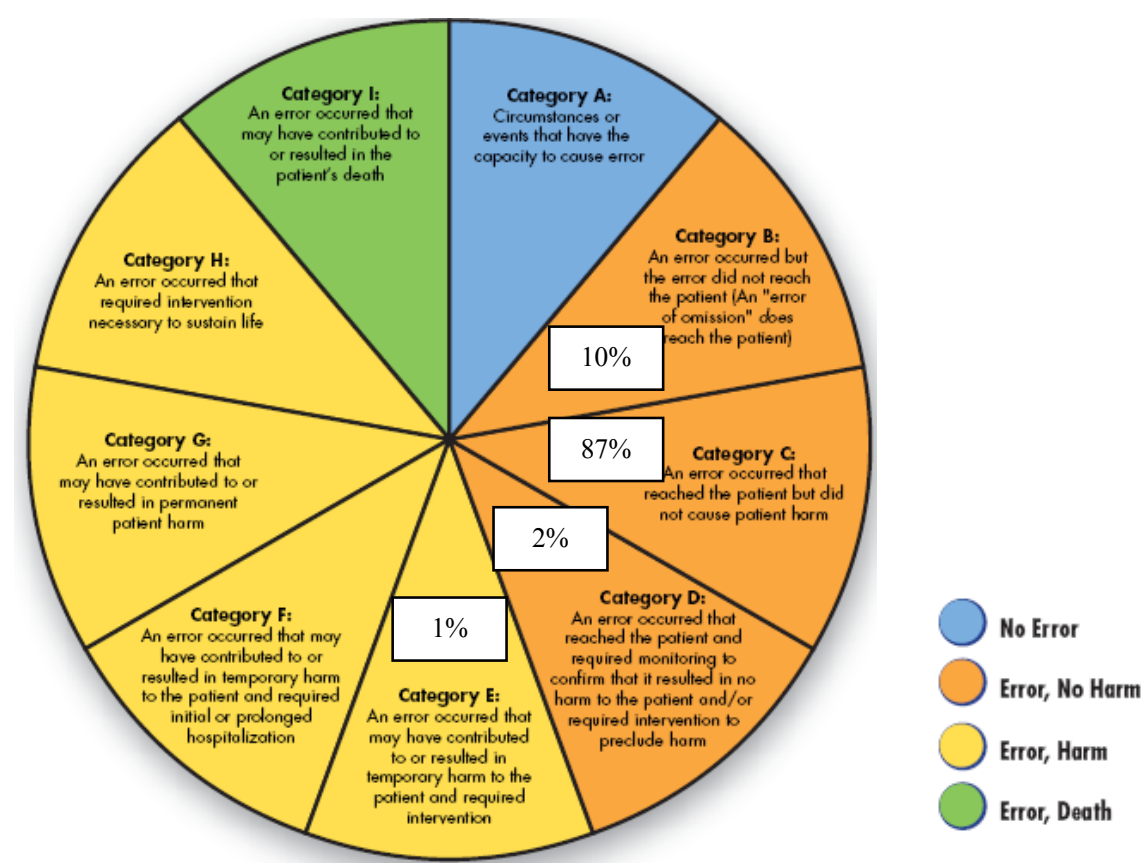

Gambar 4. Hasil pemetaan kesalahan pemberian obat pada balita oleh orang tua balita peserta posyandu di kecamatan Sukolilo

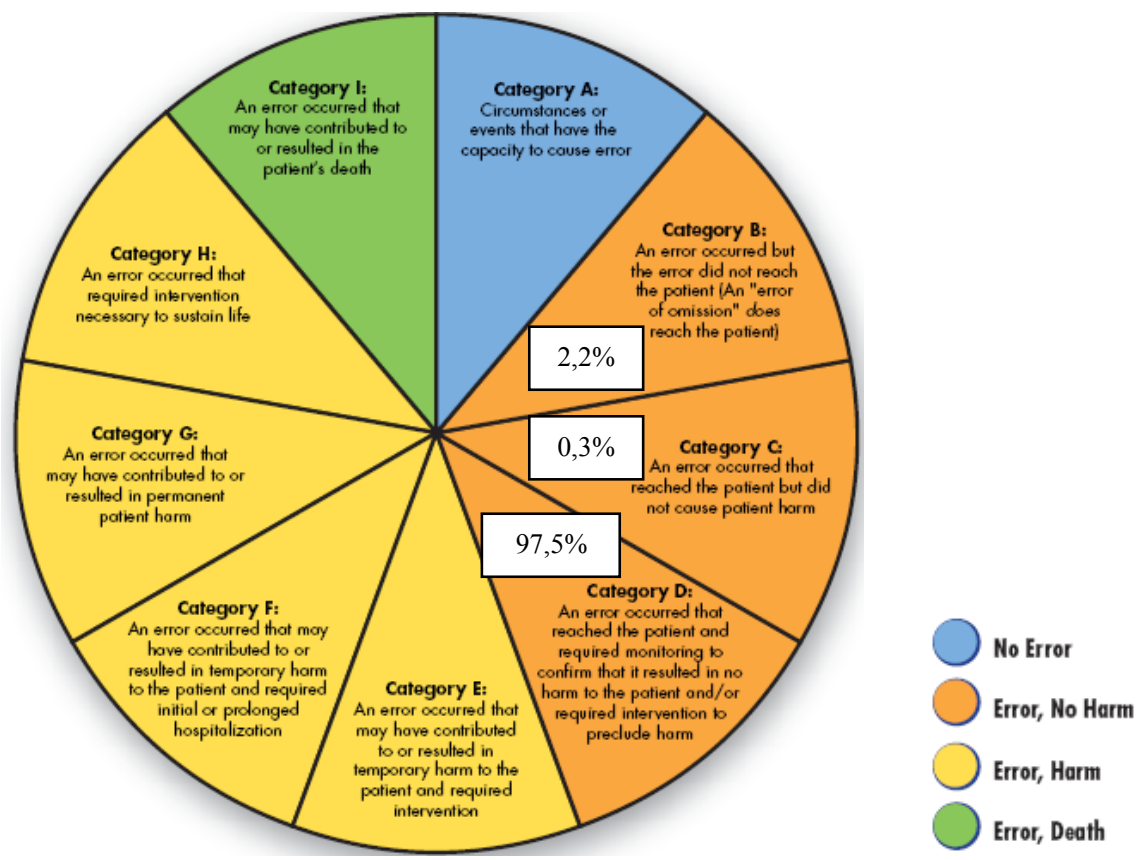

Gambar 5. Hasil pemetaan kesalahan pemberian obat pada ibu hamil peserta posyandu di kecamatan Sukolilo

dangkan kategori "E" (kesalahan telah terjadi yang dapat menyebabkan bahaya sementara bagi pasien dan memerlukan intervensi) terjadi pada balita yang mendapatkan resep dokter, namun orang tua salah dalam memberikan obat (dosis dan frekuensi pemberian obat tidak tepat), sehingga anak masih sakit serta kemudian harus dirawat di RS.
Terdapat seorang ibu balita yang meyakini bahwa anaknya menderita autisme setelah menggunakan obat dari resep dokter. Namun kejadian ini tidak dimasukkan ke dalam perhitungan kesalahan pengunaan obat, karena tidak dapat dijelaskan lebih lanjut oleh orang tua balita tersebut. 
Tabel 4. Jenis kesalahan penggunaan obat pada responden ibu hamil dan klasifikasi kesalahan penggunaan obat berdasarkan NCC-MERP (2001)

\begin{tabular}{|c|c|c|c|c|c|c|}
\hline \multirow[t]{2}{*}{ Wilayah Puskesmas } & \multirow[t]{2}{*}{ Jumlah } & \multirow[t]{2}{*}{$\%$} & \multicolumn{4}{|c|}{$\begin{array}{l}\text { Kesalahan penggunaan obat berdasarkan } \\
\text { klasifikasi NCC MERP (\%) }\end{array}$} \\
\hline & & & B & $\mathrm{C}$ & $\mathrm{D}$ & $E$ \\
\hline \multicolumn{7}{|l|}{ Keputih } \\
\hline a. Pasien & 1 & 6,25 & 2,2 & 0,3 & 97,5 & - \\
\hline b. Penyimpanan & 3 & 18,75 & & & & \\
\hline c. Obat terlewat & 6 & 37,5 & & & & \\
\hline d. Tidak melihat kadaluarsa & 5 & 31,25 & & & & \\
\hline e. Obat rusak & 1 & 6,25 & & & & \\
\hline \multicolumn{7}{|l|}{ Menur } \\
\hline a. Pasien & 2 & 12,5 & & & & \\
\hline b. Penyimpanan & 6 & 37,5 & & & & \\
\hline c. Obat terlewat & 7 & 43,75 & & & & \\
\hline d. Tidak melihat kadaluarsa & 0 & - & & & & \\
\hline e. Obat rusak & 1 & 6,25 & & & & \\
\hline \multicolumn{7}{|l|}{ Klampis } \\
\hline a. Pasien & 1 & 12,5 & & & & \\
\hline b. Penyimpanan & 3 & 37,5 & & & & \\
\hline c. Obat terlewat & 3 & 37,5 & & & & \\
\hline d. Tidak melihat kadaluarsa & 1 & 12,5 & & & & \\
\hline e. Obat rusak & 0 & - & & & & \\
\hline
\end{tabular}

Tabel 5. Jenis kesalahan penggunaan obat pada responden orang tua balita dan klasifikasi kesalahan penggunaan obat berdasarkan NCC-MERP (2001)

\begin{tabular}{lllll}
\hline $\begin{array}{l}\text { Kesalahan penggunaan } \\
\text { obat }\end{array}$ & $\begin{array}{l}\text { Puskesmas } \\
\text { Keputih (\%) }\end{array}$ & $\begin{array}{l}\text { Puskesmas } \\
\text { Klampis (\%) }\end{array}$ & $\begin{array}{l}\text { Puskesmas } \\
\text { Menur (\%) }\end{array}$ & $\begin{array}{l}\text { Kesalahan penggunaan } \\
\text { obat berdasarkan } \\
\text { klasifikasi NCC-MERP } \\
\text { (\%) }\end{array}$ \\
\hline Pemilihan obat & 2 & 2 & 3 & Kategori B : 10 \\
Indikasi & 2 & 2 & 3 & Kategori C : 87 \\
Dosis & 16 & 12 & 10 & Kategori D : 2 \\
Frekuensi & 39 & 37 & 33 & Kategori E : 1 \\
Bentuk sediaan & 0 & 0 & 1 & \\
Cara pemberian obat & 4 & 5 & 5 & \\
Penyimpanan & 15 & 17 & 18 & \\
Obat terlewat & 11 & 23 & 24 & \\
Obat rusak & 0 & 0 & 1 & \\
Efek samping obat & 9 & 0 & 1 & \\
Lain-lain & 2 & 2 & 1 & \\
\hline Total & 100 & 100 & 100 & \\
\hline
\end{tabular}

\section{Kesimpulan dan saran}

Terdapat kesalahan penggunaan obat pada ibu hamil dan balita, namun tidak menimbulkan bahaya pada pasien. Sebagian besar kesalahan penggunaan obat dapat dihindarkan, dengan pemberian infor- masi dan edukasi kepada ibu hamil dan orang tua balita mengenai cara penggunaan obat yang tepat. Disarankan kepada tenaga kesehatan, khususnya apoteker Puskesmas sebagai bagian dari tim kesehatan untuk melaksanakan pemberian informasi obat secara rutin melalui kunjungan di Posyandu. 


\section{Daftar pustaka}

1. Riset Kesehatan Dasar 2013 [diakses pada: 12 Maret 2014]. Tersedia pada: http://www.depkes. go.id/ downloads/riskesdas2013/Hasil\%20Riskesdas\%202013.

2. BKKBN. Siaran Pers: BKKBN, peduli selamatkan ibu di Indonesia [diakses pada: 8 Februari 2014]. Tersedia pada: http://www.bkkbn.go.id.

3. Dinas Kesehatan Provinsi Jawa Timur. Profil kesehatan provinsi Jawa Timur [diakses pada: 31 Januari 2014]. Tersedia pada: http://dinkes.jatimprov. go.id.

4. Notoatmodjo S. Ilmu perilaku kesehatan. Jakarta: Rineka Cipta; 2010, 27-28.

5. Notoatmodjo S. Promosi kesehatan dan ilmu perilaku. Jakarta: Rineka Cipta; 2007.

6. Fajar I, Amin I, Pudjirahaju A, dkk. Statistika untuk praktisi kesehatan. Yogyakarta: Graha Ilmu; 2009.

7. Sugiyono. Metode penelitian kuantitatif, kualitatif dan R\&D. Bandung: Alfabeta; 2013.

8. Sunyoto D. Analisa validitas dan asumsi klasik. Yogyakarta: Gaya Media; 2012.

9. Suryabrata S. Metode penelitian. Jakarta: Rajawali Pers; 2009.

10. Riwidikdo H. Statistika Kesehatan. Yogyakarta: Mitra Cendikia Press; 2009.

11. Departemen Kesehatan RI. Pedoman umum pengelolaan posyandu [diakses pada: 16 April 2014]. Tersedia pada: http://www.depkes.go.id.

12. Departemen Kesehatan RI. Buku kesehatan ibu dan anak [diakses: pada 31 Januari 2014]. Tersedia pada: http://www.depkes.go.id-downloadsjica-kia.

13. Direktorat Bina Gizi. Rencana kerja pembinaan gizi masyarakat tahun 2013 [diakses pada: 27 Januari 2014]. Tersedia pada: http://www.gizi. depkes.go.id.

14. Lampiran Peraturan Walikota Surabaya Nomor 20 Tahun 2008, Pedoman umum program pos pendidikan anak usia dini terpadu [diakses pada: 16 April 2014]. Tersedia pada: http://jdij.surabaya. go.id.

15. Aspden P, Wolcott J, Bootman JL, Cronenwertt LR. Preventing medication errors: quality chasm series. Washington DC: The National Academic Press; 2007, 1-41.

16. ASHP guidelines on preventing medication errors in hospitals. Am J Hosp Pharm. 1993;50(2):305314.

17. Jushuf IH, Ahmed, Allison SP, Barnes PRJ. British National Formulary 65. Great Britain: BMJ Group and Pharmaceutical Press; 2013.

18. Dipiro TJ, Talbert LR, Yee CG, et al. Pharmacotherapy a pathophysiologic approach, $7^{\text {th }}$ ed. United States of America: The McGraw-Hill Companies; 2008, 1639-1650.

19. Beqqs SA, Cranswick NE, Reed MD. Improving drug use for children in the developing world. Arch Dis Child. 2005;90(10):1091-1093.

20. Dundee FD, Dundee DM, Noday DM. Pediatric counseling and medication management services: opportunities for community pharmacists. Journal of the American Pharmacists Association. 2002;42(4):556-567.

21. Aliotta SL, Vlasnik JJ, Delor B. Enhancing adherence to long-term medical therapy: a new approach to assessing and treating patients. $A d v$ Ther. 2004;21(4):214-231.

22. Alwan NA, Greenwood DC, Simpson NA, McArlle HJ, Godfrrey KM, Cade JE. Dietary iron intake during early pregnancy and birth outcomes in a cohort of British women. Hum Reprod. 2011;26(4):911-919.

23. Ani LS. Anemia defisiensi besi masa prahamil dan hamil. Jakarta: Penerbit Buku Kedokteran EGC; 2013.

24. Budiarni W. Hubungan pengetahuan, sikap dan motivasi dengan kepatuhan konsumsi tablet besi folat pada ibu hamil. Semarang: Program Studi Ilmu Gizi Fakultas Kedokteran Universitas Diponegoro; 2012.

25. Galloway R, Dusch E, Elder L, Achadi E, Grajeda R, Hurtado E, Favin M, Kanani S, Marsaban J, Meda N, Moore KM. Women's preceptions of iron deficiency and anemia prevention and control in eight developing countries. Social Science \& medicine. 2002;55:529-544.

26. Milman N. Oral iron prophylaxis in pregnancy: not too little and not too much! Journal of pregnancy. 2012. 
27. Park M. Effects of interactive pictorial education on community. Dwelling older adult's self efficacy and knowledge for safe medication. 2011;41(6):795804.

28. Pavord S, Myers B, Robinson S, Allard S, Strong J, Oppenheimer $\mathrm{C}$. UK guidelines on the management of iron deficiency in pregnancy. British journal of haematology. 2012;156(5):588-600.

29. WHO. Weekly iron-folic acid supplementation (WIFS) in woman of reproductive age: its role in promoting optimal maternal and child health [diakses pada: 31 Januari 2014]. Tersedia pada: http://www.who.int-nutrion-publication.

30. WHO. Guidelines vitamin D supplementation in pregnant women [diakses pada: 1 Maret 2014]. Tersedia pada: http://www.who.int.

31. WHO. Guidelines calcium supplementation in pregnant women [diakses pada: 21 Maret 2014]. Tersedia pada: http://www.who.int.

32. Vaidya A, Williams JS. Vitamin D in the pathophysiology of hypertension, kidney disease, and diabetes: examining the relationship between vitamin $\mathrm{D}$ and the renin-angiotensin system in human diseases. Metabolism. 2012;61(4):450. 